TEME, г. XLIV, бр. 4, октобар - децембар 2020, стр. 1457-1479

\begin{tabular}{lr}
\hline \hline Оригинални научни рад & https://doi.org/10.22190/TEME200212086R \\
Примљено: 12.2 .2020$. & UDK 658.62:005
\end{tabular}

Ревидирана верзија: 2. 7. 2019.

Одобрено за штампу: 1. 12. 2020.

\title{
DECISION SUPPORT MODEL FOR SUPPLY CHAIN MANAGEMENT
}

\author{
Dragana Rejman Petrović , Predrag Mimović, Zora Arsovski \\ Faculty of Economics, University of Kragujevac, Serbia \\ *rejman@kg.ac.rs
}

\begin{abstract}
The purpose of this paper is the creation of a model for supply chain performance optimization and the development of a prototype of the decision support system.

The study covered an efficient and agile supply chain type. The Analytic Hierarchy Process was used (AHP) for the evaluation and ranking of supply chains.

The research on this topic have dealt with the evaluation and ranking of suppliers within supply chains not considering the characteristics of different types of supply chains. The contribution of this work is in the development of a new model that enables the evaluation and ranking of supply chains considering the priorities of key performance indicators in different types of supply chains, providing management with the support in decision making through simulation and the finding of optimum solutions for the specific supply chain type, as well as the possibility of evaluation and ranking of different supply chain types on the basis of weighted overall performance of each supply chain.

Developed and suggested models provide company management with monitoring and control of individual key performance indicators and total supply chain performance, and in this way, become the support to the management in strategic decision making.
\end{abstract}

Key words: $\quad$ Decision Support Model, Supply Chain Management, Performance

Measurement, Key Performance Indicator, Analytic Hierarchy Process.

\section{МОДЕЛ ПОДРШКЕ ОДЛУЧИВАҢУ ЗА УПРАВЉАЊЕ ЛАНЦИМА СНАБДЕВАЊА}

\section{Апстракт}

Сврха овог рада је осмишљавање модела за оптимизацију перформанси ланца снабдевања и развој прототипа система за подршку одлучивању. Истраживање је обухватило ефикасан и агилан тип ланца снабдевања. За евалуацију и рангирање ланаца снабдевања коришћен је аналитички хијерархијски процес (АНР). Истраживања на ову тему за предмет су имала евалуацију и рангирање добављача у оквиру ланаца снабдевања, при чему аутори нису узимали у обзир карактеристике различитих типова ланаца снабдевања. Допринос овог рада огледа се у развоју новог модела који омогућава евалуацију и рангирање ланаца снабдевања, узимајући у обзир приоритете кључних индикатора перформанси у различитим типовима ланаца снабдевања, 
обезбеђујући менаџменту подршку у одлучивању кроз симулацију и изналажење оптималног решења за конкретан тип ланац снабдевања, као и могућност евалуације и рангирања различитих типова ланаца снабдевања на основу пондерисане укупне перформансе сваког ланца снабдевања. Развијени и предложени модели обезбеђују менаџменту компанија праћење и контролу појединачних кључних индикатора перформанси и укупне перформансе ланаца снабдевања и на тај начин постају подршка менаџменту у стратегијском одлучивању.

Кључне речи: модел за подршку одлучивању, управљање ланцима снабдевања, мерење перформанси, кључни индикатори перформанси, аналитички хијерархијски процес.

\section{INTRODUCTION}

Managing the supply chain is a paradigm that has attracted attention of researchers in the last few decades. Researchers invest significant efforts in order to develop models for deciding and solving the problems related to the area of managing supply chains (Croxton et al.,2001; Forslund, 2015; Guan \& Rehme, 2012; Sahay et al., 2006; Ishizaka \& Labib, 2011; Panahifar et al., 2018; Lambert et al., 2008; Li \& Lin, 2006; Lo \& Yeung, 2004; MellatParast \& Spillan, 2014; Sanders et al., 2011). Supply chain management demands multi-criteria decision making because then the management takes into account the different criteria and the accompanying sub-criteria.

In this paper, the focus is placed on the calculation of the total performance of the supply chain and the paper illustrates the possibility of the rating of various supply chain types, since the research until now have mainly dealt with individual performance indicators of supply chain or the ranking of suppliers. Hence, the focus of this study is on the total measure of supply chain that is obtained by weighting and integration of individual performance indicators that were previously identified as the key ones in the process of the evaluation of total supply chain.

This paper shows the development of the models for supply chain performance optimization and total supply chain performance calculation, as well as the development of a system prototype for the support to decision making of supply chains.

\section{MODEL FOR THE ANALYSIS, MEASUREMENT AND OPTIMIZATION OF SUPPLY CHAIN PERFORMANCE}

The suggested model for analysis, measurement and optimization of the supply chain performance includes two modules. The first module implies the definition of the types of observed supply chains, key performance indicators (KPI), their priorities and target values depending on the supply chain type, the evaluation and ranking of different types on the basis of the AHP model (Saaty, 1980; Saaty \& Kearns, 1985; Sipahi \& Timor, 2010; Subramanian \& Ramanathan, 2012; Deng, Hu, Deng, \& 
Mahadevan, 2014; Ishizaka \& Labib, 2011 and Dweiri, Kumar, Khan, \& Jain, 2016. The outputs of this model represent the inputs that enable the functioning of the second module that refers to the calculation of the total performance of supply chains (Figure 1).

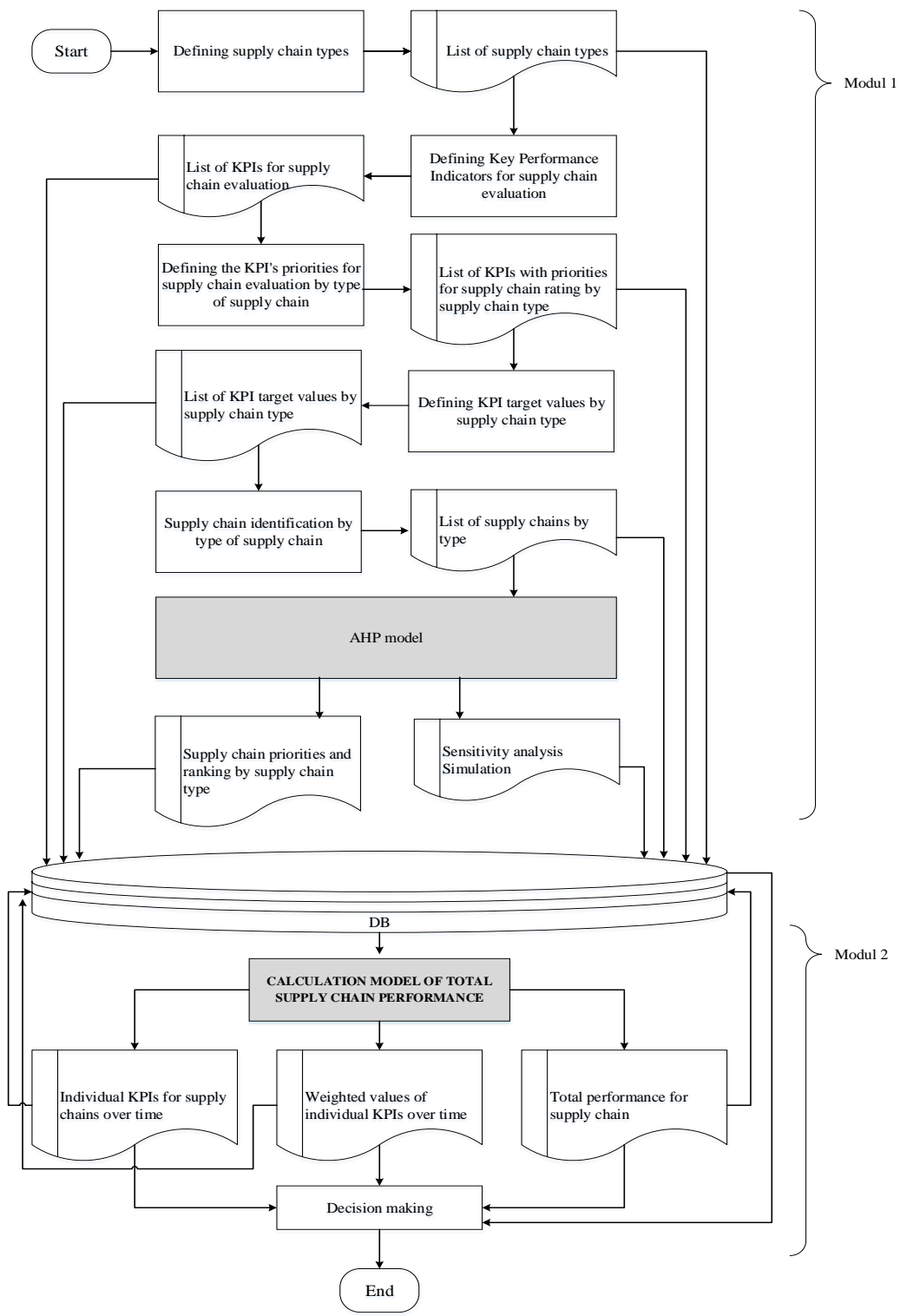

Figure 1. Steps and procedure of multi-criteria model for analysis, measurement and optimization supply chain performance

Source: Authors 
In this paper, the authors based their research on two types of supply chains and the priorities of measures, sub-measures and metrics defined by Chibba (2007), which also served to structure the appropriate AHP model.

\section{PROBLEM DESCRIPTION AND STRUCTURING OF AHP MODEL}

At all the management levels, the existence of data that are the result of everyday monitoring of organization business is necessary. Since this involves a large amount of data that emerges in different places, it is necessary for such data to be organized in data bases within the information system. It is very important for such data bases to reflect the real state of the business system. Data bases in that sense represent a source of information that is used in decision making on strategic, tactic and operational levels. Such data bases are in the service of the creation of integrated and subject oriented information.

The objectives of this research are:

- Establishing key criteria in the process of evaluation and ranking of supply chains,

- Development of AHP model of multi-criteria decision making,

- Evaluation of set criteria and their evaluation with the help of AHP methods and

- Testing the model with the help of software for the support in decision making SuperDecisions and the analysis of obtained results.

By the application of the AHP method the following is presented:

- The possibility of evaluation and ranking of several supply chains within the same type of supply chains,

- The calculation of the total performance of supply chains,

- The possibility of mutual comparison of supply chain performances from different types,

- The analysis of the change impact of relative importance of chosen criteria on final priorities and range of supply chain,

- The analysis of change impact of sub-criteria priorities (defined KPI) on the priority and range of supply chain and

- The evaluation of suppliers and determining their priority and range depending on which type of supply chain they belong to.

Defining model objective is one of the most important steps with the problem of decision making. Decision making is a process that is completely dependent on the human factor, thus due to the expressed element of subjectivity the way of solving problems, as well as the choice of criteria on the basis of which we will evaluate alternatives, also depends on the defined objective. The same decision maker can, in 
unchanged conditions, act differently depending on what objective he wants to achieve by the analysis. The objective of this model is the analyzing of supply chains, and their evaluation, so that on the basis of performance, it could be perceived and decided on where it is necessary to react for the purpose of performance improvement.

Starting from the defined objective, the following relevant criteria for managerial decision making are defined, as well as the sub-criteria that explain them more closely.

The model criteria are:

- delivery efficiency $(\mathrm{C} 1)$,

- receipt efficiency $(\mathrm{C} 2)$ и

- transport costs (C3).

Sub-criteria are:

- On time delivery from supplier (SOTD),

- Discrepant material report from supplier (SDMR),

- Parts per million from supplier (SPPM),

- Cost of poor quality from supplier (SCPQ),

- On time delivery to customer (COTD),

- Discrepant material report to customer (CDMR),

- Parts per million to customer (CPPM),

- Cost of poor quality to customer (CCPQ),

- Inbound transport costs - regular (ITCR),

- Inbound transport costs - extraordinary (ITCE),

- Outbound transport costs - regular (OTCR) and

- Outbound transport costs - extraordinary (OTCE) (Rejman Petrović, D., 2015).

The alternatives in the model represent three supply chains SC1, SC2 and SC3.

The appropriate AHP model is formed, with four corresponding levels of decision making, as follows:

- Goal level - evaluation of supply chain,

- Criteria level - C1, C2, C3,

- Sub-criteria level - a set of sub-criteria based on common characteristics and

- Alternative level - a set of alternatives SC1, SC2, SC3.

The hierarchical structure of the AHP model ${ }^{1}$ for supply chain evaluation, ranking, and comparison is shown in Figure 2.

\footnotetext{
${ }^{1}$ The model is developed by using special software for the support in decision making SuperDecisions
} 




Figure 2. The hierarchical structure of the AHP model for supply chain Source: Rejman Petrović, 2015

Key performance indicators that determine the total supply chain performance are expressed in different measure units and their target values are shown in Table 1.

Table 1. Key performance indicators that determine the total supply chain performance

\begin{tabular}{lccc}
\hline Key performance indicators & & $\begin{array}{c}\text { Unit of } \\
\text { measure }\end{array}$ & $\begin{array}{c}\text { Target } \\
\text { value }\end{array}$ \\
\hline On time delivery from supplier & SOTD & $\%$ & $100 \%$ \\
Discrepant material report from supplier & SDMR & $\mathrm{ppm}$ & $0 \mathrm{ppm}$ \\
Parts per million from supplier & SPPM & $\mathrm{ppm}$ & $0 \mathrm{ppm}$ \\
Cost of poor quality from supplier & SCPQ & $\%$ sales & $0 \%$ \\
On time delivery to customer & COTD & $\%$ & $100 \%$ \\
Discrepant material report to customer & CDMR & $\mathrm{ppm}$ & $0 \mathrm{ppm}$ \\
Parts per million to customer & CPPM & $\mathrm{ppm}$ & $0 \mathrm{ppm}$ \\
Cost of poor quality to customer & $C C P Q$ & $\%$ sales & $0 \%$ \\
Inbound transport costs - regular & $I T C R$ & $\%$ net sales & $3,50 \%$ \\
Inbound transport costs - extraordinary & $I T C E$ & $\%$ net sales & $0 \%$ \\
Outbound transport costs - regular & OTCR & $\%$ net sales & $3,50 \%$ \\
Outbound transport costs - extraordinary & OTCE & $\%$ net sales & $0 \%$ \\
\hline
\end{tabular}

Source: Rejman Petrović, 2015

\section{MODEL RESULTS}

By pairwise comparison of decision making elements in accordance with the assumed dependences, and according to the usual scale 1-9 in the observed problem (table 2 and 4 ), the prioritization is done by the method of 
characteristic value, where weight coefficients of the criterion, depending on the supply chain type, are obtained and they enable the ranking of the observed elements according to the preferences of decision makers that performed the assessments. On the basis of management assessment in the observed organizations for the efficient type of supply chain, the biggest priority is assigned to the costs criterion, and less and equal criteria to receipt efficiency and delivery efficiency (Table 3), while for agile types of supply chain the biggest and equal priority is assigned to the criteria receipt efficiency and delivery efficiency, and less priority to the costs criterion (Table 5).

Table 2. Matrix of comparison of the criteria for the evaluation of efficient SC type, using the scale of comparison 1-9

\begin{tabular}{lccc}
\hline Criteria & Delivery efficiency & Receipt efficiency & Transport costs \\
\hline Delivery efficiency & 1 & 1 & $1 / 5$ \\
Receipt efficiency & 1 & 1 & $1 / 5$ \\
Transport costs & 5 & 5 & 1 \\
\hline \multicolumn{4}{c}{ Source: Authors }
\end{tabular}

Table 3. Relative weights of the criteria for evaluating supply chain factors (efficient SC type)

\begin{tabular}{lc}
\hline Criteria & Weights \\
\hline Delivery efficiency & 0.142857 \\
Receipt efficiency & 0.142857 \\
Transport costs & 0.714286 \\
\hline
\end{tabular}

Source: Authors

Table 4 Matrix of comparison of the criteria for the evaluation of agile SC types, using the scale of comparison 1-9

\begin{tabular}{lccc}
\hline Criteria & Delivery efficiency & Receipt efficiency & Transport costs \\
\hline Delivery efficiency & 1 & 1 & 5 \\
Receipt efficiency & 1 & 1 & 5 \\
Transport costs & $1 / 5$ & $1 / 5$ & 1 \\
\hline \multicolumn{4}{c}{ Source: Authors }
\end{tabular}

Table 5 Relative weights of the criteria for evaluating supply chain factors (agile SC type)

\begin{tabular}{ll}
\hline Criteria & Weights \\
\hline Delivery efficiency & 0.45455 \\
Receipt efficiency & 0.45455 \\
Transport costs & 0.09091 \\
\hline
\end{tabular}

Source: Authors 
Each criterion is more closely explained through its sub-criteria, by which more detailed and realistic analysis level is reached. Within each criterion, the sub-criteria are mutually compared in relation to the criterion they describe, also according to the scale 1-9. This means, at the same time, that the alternatives will be mutually compared in relation to each subcriterion, which enables the ranking of alternatives in accordance with the preferences of decision makers, i.e. the management that performs the assessment. Final priorities and the order of alternatives according to the rank are shown in Table 6 for the efficient and agile supply chain type. According to the synthesized managerial assessments, for the efficient supply chain type the highest priorities are assigned to costs, while for agile supply chain type the highest priorities are assigned to deliveries on time, i.e. SOTD and COTD (Arsovski \& Rejman Petrović, 2017).

Table 6. Key Performance Indicator Priorities (KPIs)

\begin{tabular}{lcccc}
\hline \multirow{2}{*}{ Alternatives } & \multicolumn{2}{c}{ Efficient SC type } & \multicolumn{2}{c}{ Agile SC type } \\
\cline { 2 - 5 } & Priorities & Rank & Priorities & Rank \\
\hline SOTD & 0.05 & 8 & 0.25 & 1 \\
SDMR & 0.02 & 9 & 0.05 & 5 \\
SPPM & 0.00 & 12 & 0.11 & 3 \\
SCPQ & 0.05 & 7 & 0.03 & 9 \\
COTD & 0.05 & 6 & 0.25 & 2 \\
CDMR & 0.01 & 11 & 0.05 & 6 \\
CPPM & 0.01 & 10 & 0.11 & 4 \\
CCPQ & 0.05 & 5 & 0.03 & 10 \\
ITCR & 0.06 & 4 & 0.00 & 11 \\
ITCE & 0.21 & 2 & 0.03 & 8 \\
OTCR & 0.06 & 3 & 0.00 & 12 \\
OTCE & 0.36 & 1 & 0.03 & 7 \\
\hline & Source: Rejman Petrović, 2015 & &
\end{tabular}

On the basis of the previously mentioned, we came to the final rank of supply chains. The final rank of supply chains for agile and efficient supply chain type is given in Table 7.

Table 7 Priorities and ranking of observed supply chains

\begin{tabular}{lcccc}
\hline \multirow{2}{*}{ Alternatives } & \multicolumn{2}{c}{ Efficient SC type } & \multicolumn{2}{c}{ Agile SC type } \\
\cline { 2 - 5 } & Priorities & Rank & Priorities & Rank \\
\hline SC 1 & 0.3794 & 2 & 0.4674 & 1 \\
SC 2 & 0.1971 & 3 & 0.2859 & 2 \\
SC 3 & 0.4235 & 1 & 0.2468 & 3 \\
\hline \multicolumn{3}{r}{ Source: Rejman Petrović, 2015 }
\end{tabular}




\section{SOLUTION SENSITIVITY ANALYSIS - CHANGE IMPACT OF RELATIVE IMPORTANCE OF KPI ON THE PRIORITIES AND RANK OF SUPPLY CHAINS}

Solution sensitivity analysis can help to observe how the weight coefficient changes, i.e. how the relative importance of sub-criteria impacts global priorities of alternatives, i.e. supply chains (Figure 3, 4, 5, 6). For example, the analysis of the relative importance change of transport costs criteria on the priority and rank of supply chains has been shown in the Figures 3 and 4. It can be noticed that the increase of relative importance of this criteria affects the reduction of supply chain rank SC3, while it leads to the increase of supply chain rank SC2.

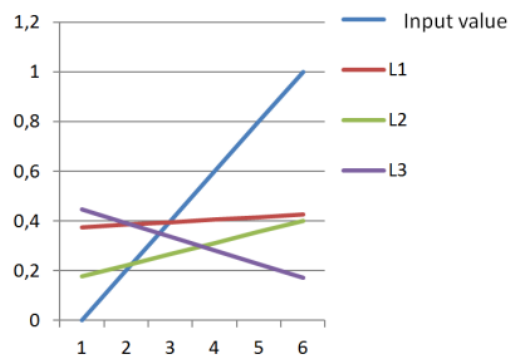

Figure 3. The impact of changing the relative importance of the Transport costs criterion on supply chain priorities and rankings (efficient SC type)

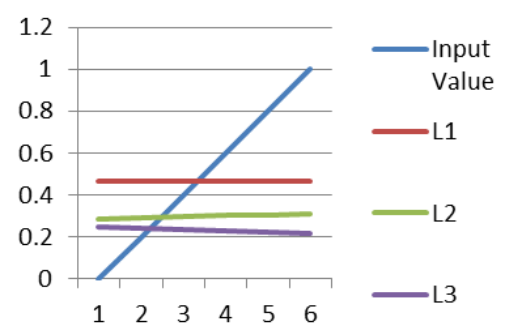

Figure 4. The impact of changing the relative importance of the Transport costs criterion on supply chain priorities and rankings (agile SC type)

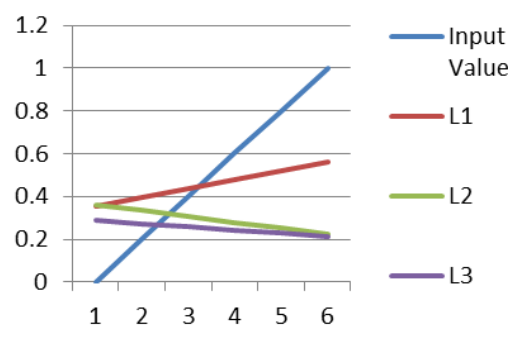

Figure 5. The impact of changing the relative importance of the Delivery efficiency criteria on supply chain priorities and rankings (efficient SC type)

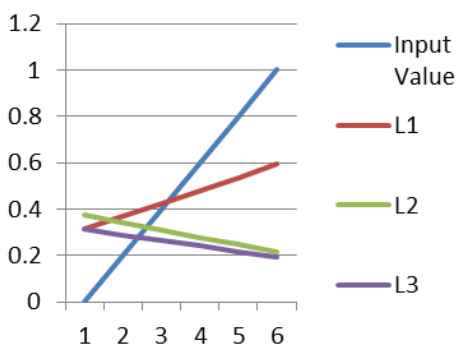

Figure 6. The impact of changing the relative importance of the Receipt efficiency criteria on supply chain ranking priorities (agile SC type) 
It is possible to observe and analyze the impact of the simultaneous change of two criteria on the rank of alternatives. Thus simultaneous growth of relative importance of delivery and receipt efficiency criteria in the efficient supply chain leads to the change in alternative rank (Figure 7 ), and there is a similar occurrence in the agile supply chain where the simultaneous growth of relative importance in certain intervals also leads to the change in the alternative rank (Figure 9).

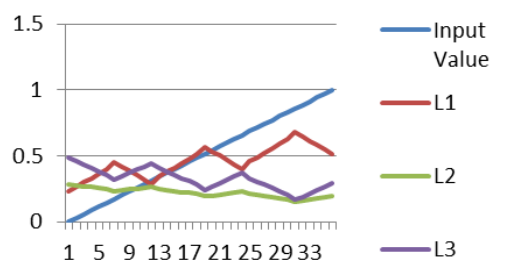

Figure 7. Impact of simultaneous change of criteria Shipping Efficiency and Receiving Efficiency on priorities and ranking alternatives (efficient SC type)

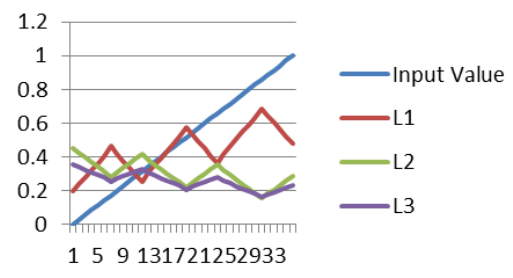

Figure 8. Impact of simultaneous change of criteria Shipping Efficiency and Receiving Efficiency on priorities and ranking alternatives (agile $S C$ type)

Further analysis included the analysis of the sub-criteria priorities changes, i.e. key performance indicators on the priority and rank of observed supply chains, since it can be important for the process of decision making. Thus the change of priorities of some KPI does not lead to priority change and rank of observed supply chains (Figure 10), while at others it leads to the inversion of rank (Figure 9, 11 and 12). Similar analysis can be carried out for all the observed KPI.

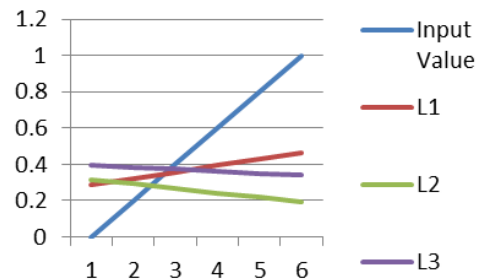

Figure 9. The impact of changing the priorities of the SOTD indicator, on the priorities and rank of the observed supply chains (efficient SC type)

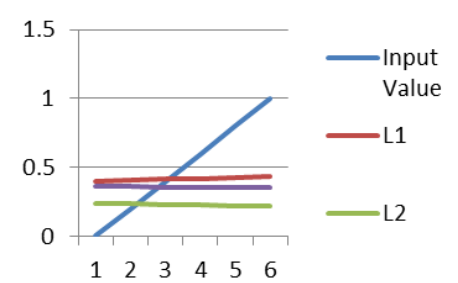

Figure 10. The impact of changing the priorities of the SDMR indicators, on the priorities and rank of the observed supply chains (efficient SC type) 


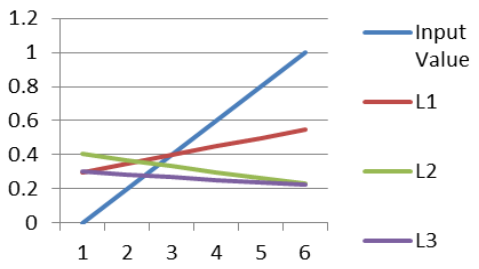

Figure 11. The impact of changing

COTD indicator priorities, on the priorities and ranking of the observed supply chains (agile SC type)

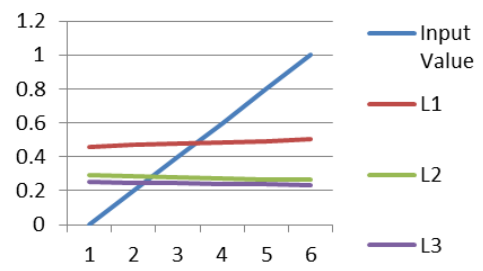

Figure 12. The impact of changing the priorities of the CDMR indicators, on the priorities and rank of the observed supply chains (agile SC type)

\section{CALCULATION MODEL OF TOTAL SUPPLY CHAIN PERFORMANCE}

The suggested model for calculation of total supply chain performance uses the evaluation marks obtained from AHP model and real data on KPI in three types of supply chains. Target values are defined as maximum or minimum values depending on the observed KPI.

In the calculation of total performance measure (Table 10, Table 11, Table 12, Table 13, Table 14, Table 15) the authors followed the following steps:

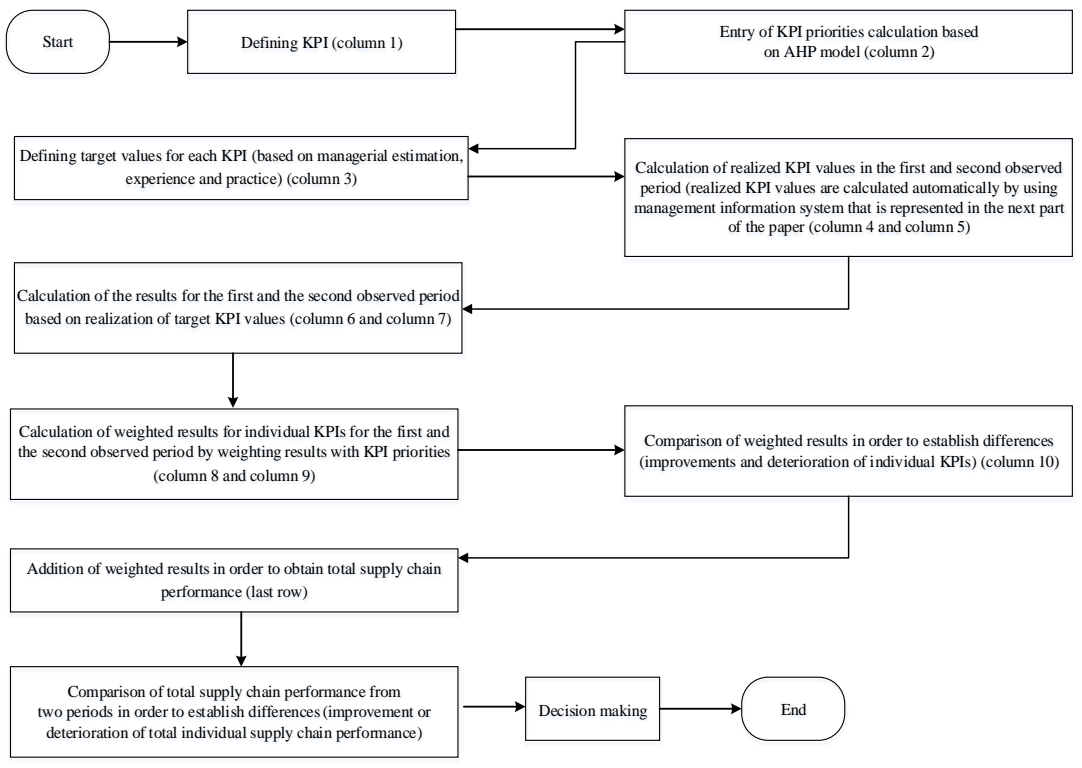

Figure 13. Steps and procedure in the calculation model of total supply chain performance 
On the basis of KPI priority values, target and realized values for each KPI, it is possible to calculate the total performance for each supply chain separately. Such value of total performance becomes a comparable size, regardless of the type of the supply chain, and enables the monitoring of performance of one supply chain in various observation periods, as well as the comparison and monitoring of performance of several supply chains of different types. The value of total performance of the supply chain is 100 in case that for each KPI the target value is realized. In case when the realized values of some or all KPI are below their target values (or above in case of costs) the total performance for the supply chain will be less than 100 . The following tables present the possibility of such measuring and monitoring of individual performance, the total performance of a specific supply chain and comparison of performance of various supply chains.

In Table 8, the priorities of KPI, target values of KPI, realized values of KPI, weighted values of KPI and total performance measured in various time periods were given for supply chains SCe1. Similarly, these values are calculated for other supply chains, and their weighted total performance is shown in Table 9.

Table 8. Weighted KPIs and total supply chain performance for efficient SC type (SCe1)

\begin{tabular}{|c|c|c|c|c|c|c|c|c|c|}
\hline KPI & $\begin{array}{c}\text { Priority } \\
\text { of } \\
\text { KPI }\end{array}$ & $\begin{array}{c}\text { Target } \\
\text { values of } \\
\text { KPI }\end{array}$ & $\begin{array}{l}\text { Realized } \\
\text { KPI } \\
\text { values in } \\
\text { the first } \\
\text { period }\end{array}$ & $\begin{array}{l}\text { Realized } \\
\text { KPI } \\
\text { values in } \\
\text { the } \\
\text { second } \\
\text { period }\end{array}$ & $\begin{array}{l}\text { The } \\
\text { result for } \\
\text { the first } \\
\text { period }\end{array}$ & $\begin{array}{l}\text { The } \\
\text { result for } \\
\text { the } \\
\text { second } \\
\text { period }\end{array}$ & $\begin{array}{l}\text { The } \\
\text { weighted } \\
\text { result for } \\
\text { the first } \\
\text { period }\end{array}$ & $\begin{array}{l}\text { The } \\
\text { weighted } \\
\text { result for } \\
\text { the } \\
\text { second } \\
\text { period }\end{array}$ & Differences \\
\hline SOTD & 0.055 & $100 \%$ & $99 \%$ & $99.60 \%$ & 99.00 & 99.60 & 5.445 & 5.478 & 0.033 \\
\hline SDMR & 0.021 & $0 \mathrm{ppm}$ & 400 & 600 & 99.96 & 99.94 & 2.099 & 2.098 & -0.001 \\
\hline SPPM & 0.009 & $0 \mathrm{ppm}$ & 150 & 50 & 99.98 & 99.99 & 0.899 & 0.899 & 0.000 \\
\hline SCPQ & 0.055 & $0.00 \%$ & $1.20 \%$ & $0.20 \%$ & 98.80 & 99.80 & 5.434 & 5.489 & 0.055 \\
\hline COTD & 0.056 & $100 \%$ & $100 \%$ & $100 \%$ & 100.00 & 100.00 & 5.600 & 5.600 & 0.000 \\
\hline CDMR & 0.014 & $0 \mathrm{ppm}$ & 400 & 350 & 99.96 & 99.96 & 1.399 & 1.399 & 0.000 \\
\hline СРPM & 0.016 & $0 \mathrm{ppm}$ & 150 & 160 & 99.98 & 99.98 & 1.599 & 1.599 & 0.000 \\
\hline CCPQ & 0.056 & $0.00 \%$ & $0.05 \%$ & $0.07 \%$ & 99.95 & 99.93 & 5.597 & 5.596 & -0.001 \\
\hline ITCR & 0.063 & $1.00 \%$ & $1.20 \%$ & $1.00 \%$ & -20.00 & 100.00 & -1.260 & 6.300 & 7.560 \\
\hline ITCE & 0.219 & $0.00 \%$ & $0.20 \%$ & $0.30 \%$ & 99.80 & 99.70 & 21.856 & 21.834 & -0.022 \\
\hline OTCR & 0.065 & $3.50 \%$ & $3.80 \%$ & $3.60 \%$ & -8.57 & -2.85 & -0.557 & -0.185 & 0.372 \\
\hline OTCE & 0.366 & $0.00 \%$ & $0.14 \%$ & $0.11 \%$ & 99.86 & 99.89 & 36.548 & 36.559 & 0.011 \\
\hline Total & & & & & & & 84.659 & 92.666 & \\
\hline
\end{tabular}

Source: Rejman Petrović, 2015 
Table 9. Weighted overall supply chain performance

\begin{tabular}{ccc}
\hline Supply chain & $\begin{array}{c}\text { The weighted result for } \\
\text { the first period (Total) }\end{array}$ & $\begin{array}{c}\text { The weighted result for the } \\
\text { second period (Total) }\end{array}$ \\
\hline SCe1 & 84.659 & 92.666 \\
SCe2 & 83.861 & 84.794 \\
SCe3 & 85.949 & 85.228 \\
SCa1 & 97.983 & 99.073 \\
SCa2 & 97.696 & 98.732 \\
SCa3 & 99.151 & 97.887 \\
\hline \multicolumn{3}{c}{ Source: Authors }
\end{tabular}

The developed model enables the assessment of performance difference in each period separately. Given that KPI, which are used in the model are expressed in various measures, it is very difficult to evaluate or compare the observed performance. In this way in the model, each measured value is weighted in accordance with the objectives, so it is possible to compare total performance score (Figure 14).

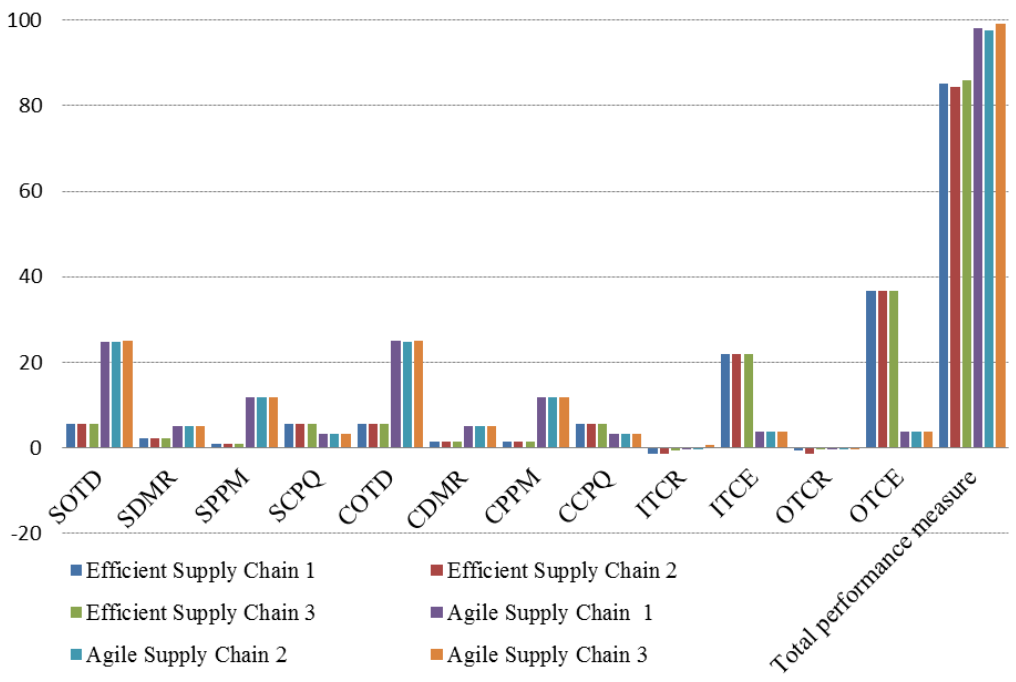

Figure 14 Total performance score Source: Authors

The noticeable improvements or deteriorations of individual KPI are also discernable, as well as the total performance and that takes place between two measurement periods.

Apart from the fact that it is possible to monitor the movement of the individual KPI, with the application of this model, it is possible to calculate the total performance of various types of supply chains, and in this way to enable their comparison, which represented the main objective 
of this research. Hence, the evaluation and ranking of several supply chains from various types of supply chains is possible, which provides management with good basis for decision making in terms of which supply chain necessitates a correction to the specific KPI for the purpose of improvement of its total performance, as well as how the correction of certain KPI would affect the total performance of that supply chain. It is possible to monitor supply chain performance in time, so that the analysis of the obtained results enables the comparison of performance during various time periods.

The presented outputs from AHP are incorporated into the database, so that the concrete results obtained by multi-criteria optimization of the proposed model, as well as the knowledge of experts consulted during the preparation of this paper, are included in the management information system for business process improvement in e-supply chains. All this makes this system the system for the support in decision making, having in mind that its basic objective is to support business processes of decision making.

\section{DEVELOPED PROTOTYPE \\ OF DECISION-MAKING SUPPORT SYSTEM}

Decision making at all management levels requires data resulting from daily monitoring of the organization's operations. Since there is a large amount of data in different places, it is necessary that such information is organized in a database within the information system. It is very important that the database reflects the current state of the business system. The database in this regard is the source of information used in decision-making at the strategic, operational, and tactical levels. Such a database is used to create integrated and object-oriented information.

When developing a prototype of the decision support system, data modeling process starts with the organization model. The data model is developed during the detailed process modeling, the analysis of data streams and documents, and the identified information needs that are relevant to a specific business area. Logical data model (Figure 15) is made using the ER win software tool (Rejman Petović, 2016).

Developed prototype enables the management the possibility to create:

- specific reports that incorporate industry requirements,

- tables with filter possibilities in order to overview the influence of the specific data,

- user friendly visualization of KPIs reports,

- ad hoc queries and report based on data defined by the users,

- forecasting, what-if scenario analysis, and analyze data using standard statistical tools. 
The developed model is flexible and enables constant analysis, measurement, monitoring and optimization of supply chain performance.

Application of the developed prototype allows the organization's management to optimize KPIs in the business processes of supply, logistics, and sales, in order to achieve better financial results.



Figure 15. Data model measurement KPI in supply chains Source: Rejman Petrović, 2016 
Having the data related to suppliers orders at disposal, by the reception of suppliers' products, the claims by the suppliers, the shipment of finished products to customers, the claims by the customers, via developed prototype of information system, we come to the assessment of delivery efficiency and receipt efficiency. The assessments of delivery and reception efficiency are obtained by the observation of realized values PPM, OTD and the amount of bad quality costs. The value of PPM is obtained automatically from the system because there is a record on claimed amounts and total delivered amounts. Created reports show the delivery efficiency to customers and reception efficiency from the supplier and include the above mentioned key performance indicators (Figure 16 and 17).

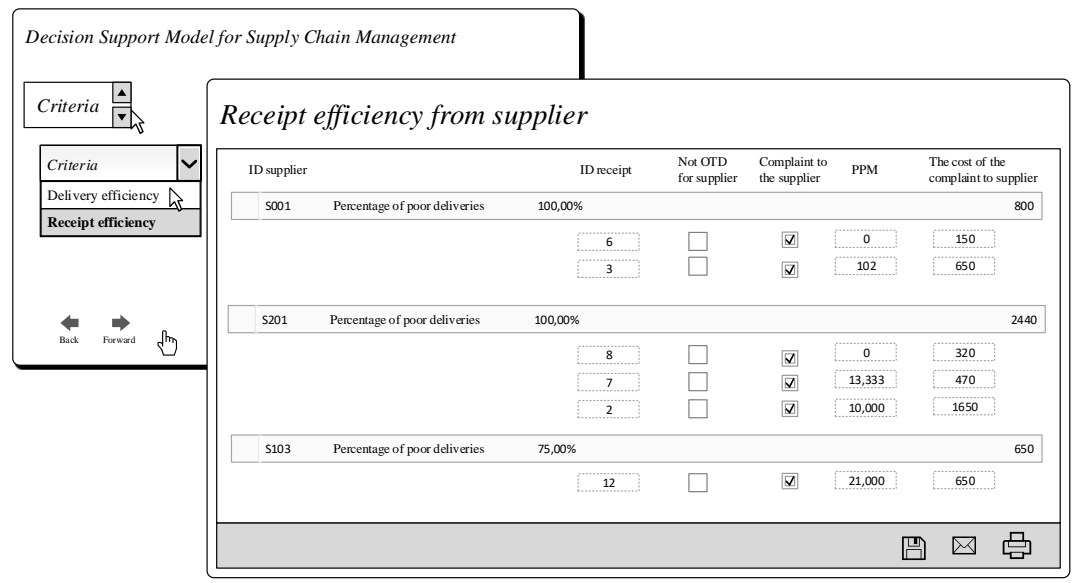

Figure 16. Receipt efficiency report from supplier

\section{Source: Authors}

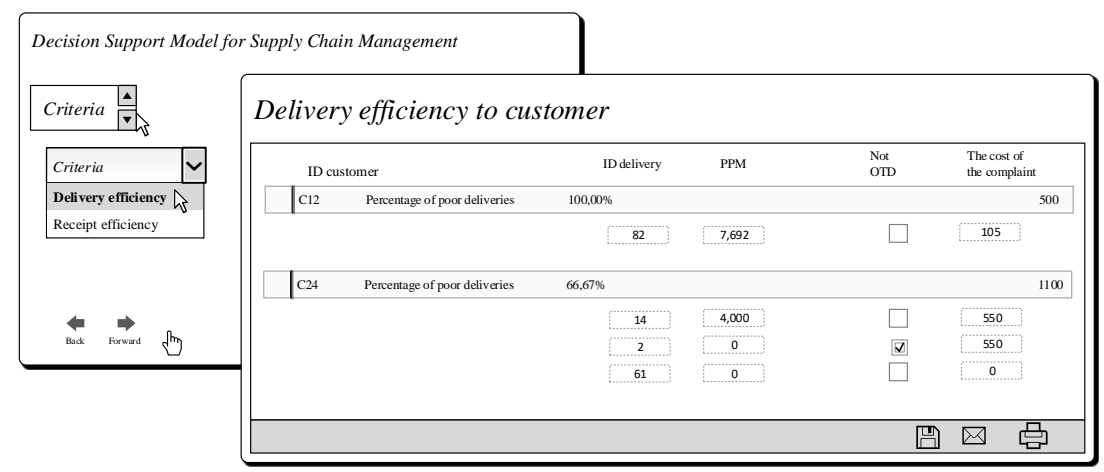

Figure 17. Delivery efficiency report to customer Source: Authors 
The system includes the analysis of transport costs within which realized inbound transport costs and outbound transport costs and their participation in total transport costs are measured and analyzed. In this figure, the display of these costs for January and February 2019 can be seen.

The system also monitors and measures regular and extraordinary costs of inbound and outbound transport and compares them with planned costs of inbound and outbound transport that are contained in the sales price of product. Figure 18 show the movement of these costs in the first two months of 2019.

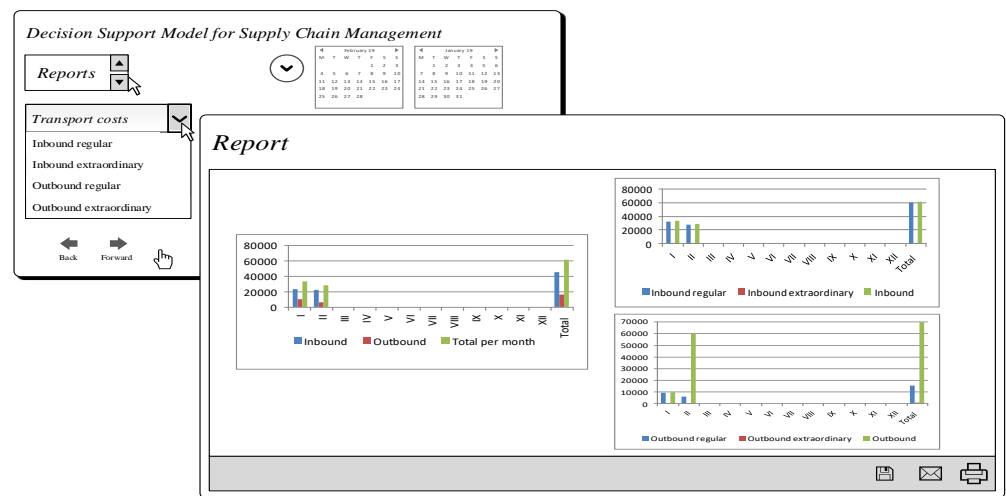

Figure 18. 125 Transport costs

Source: Authors

The specificity of this management information system for the business processes performance improvement in supply chains is a new functionality that is reflected in the possibility of the identification of supply chain types in which the observed organization is one of the links in supply chain (Figure 19).

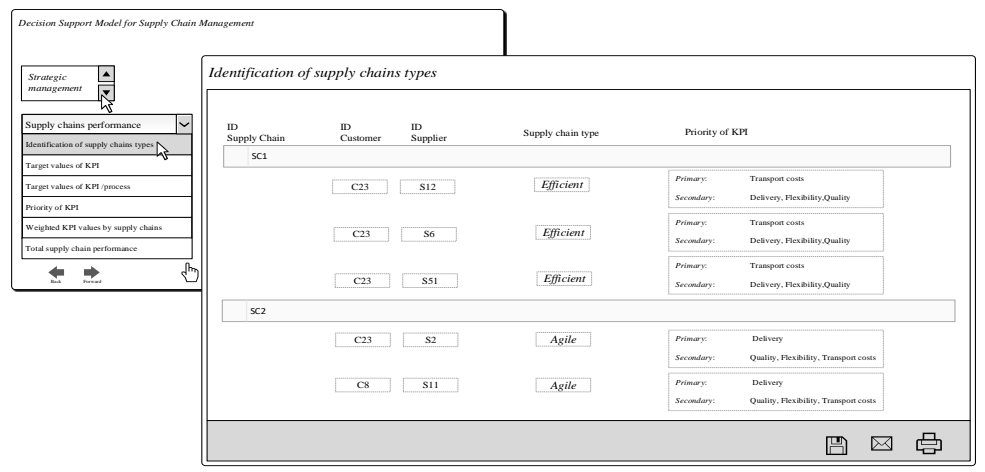

Figure 19. Supply chain types identification report Source: Authors 
Also, the system automatically calculates KPI of various business processes and gives information, on one hand, on KPI receipt, by which the side of supplier in a supply chain is being evaluated, and on the other hand, KPI of delivery of the observed organization, by which delivery efficiency to customers and the satisfaction of customers towards the organization as their supplier is being evaluated.

As it was already mentioned, in different types of supply chains, there is a different impact coefficient of KPI on the total supply chain performance. In that sense, it can be said that for different SC types some KPI will be more influential, i.e. that they will be the first priority, while the other, of the same importance, will be the second priority. For example, if we speak of agile supply chain type, KPI delivery on time is the first priority is, while the costs of KPI are the second priority.

A step forward of this information system, apart from the above mentioned, represents the possibility of the simulation of KPI set characteristic for a certain SC type, for the purpose of optimization and the increase of the total supply chain performance. Hence, there is a possibility of simulation of different values of each KPI in the set, and the analysis of its impact on the total supply chain performance. Furthermore, it enables the simulation to be performed comparatively for other supply chains as well for the purpose of the realization of optimal supply chains performance.

The simulation possibility is important due to the reason that one or more suppliers can be mutual for two or more supply chains of different type, so that KPI for one supply chain will be in the group of first priority, and for the others in the group of second priority, and in this way they will practically clash. In an identical way, the simulation of the suppliers' rank is possible depending on which type of supply chain they belong to.

In Figures 20, 21, 22 and 23 some of the reports that follow KPI and their weighted values important for KPI analysis and monitoring are shown.

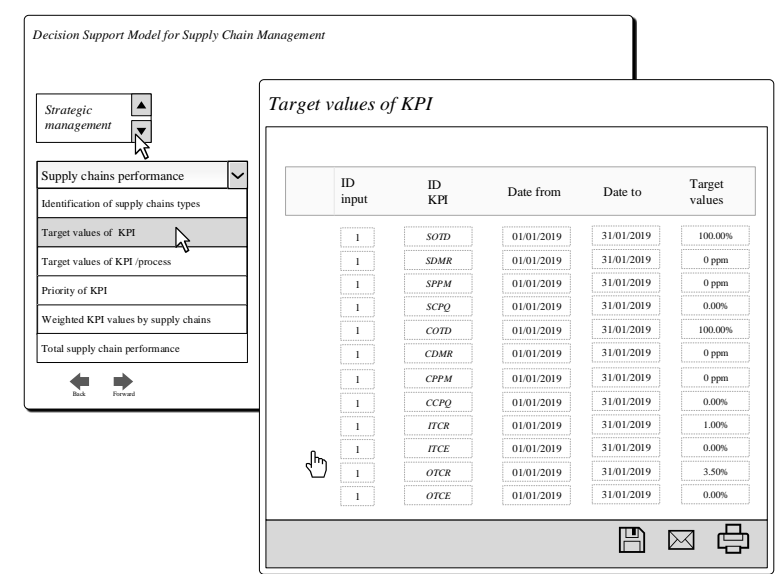

Figure 20. Target values of key performance indicators report Source: Authors 


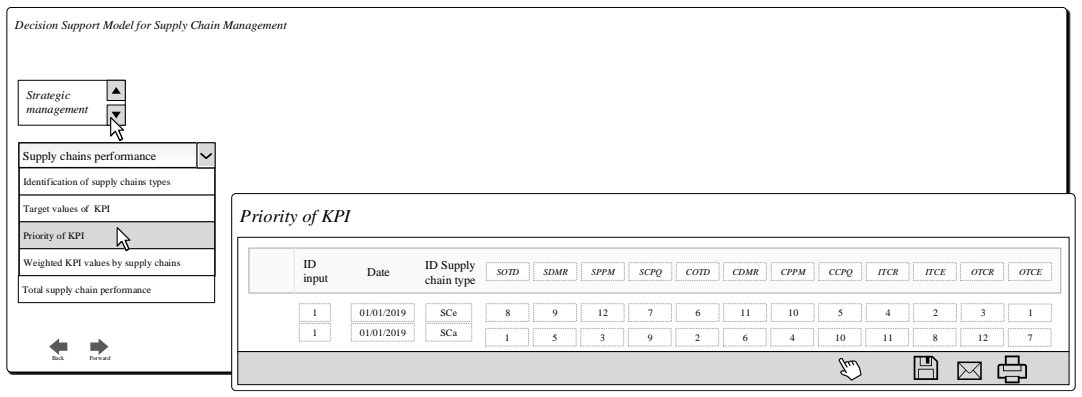

Figure 21. Priority of KPI report

Source: Authors

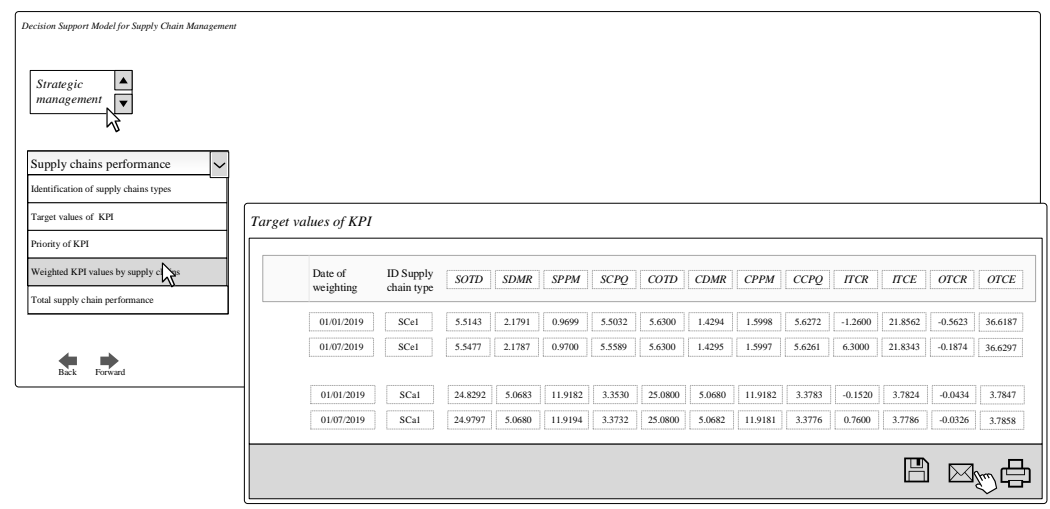

Figure 22. Weighted KPI values by supply chain Source: Authors

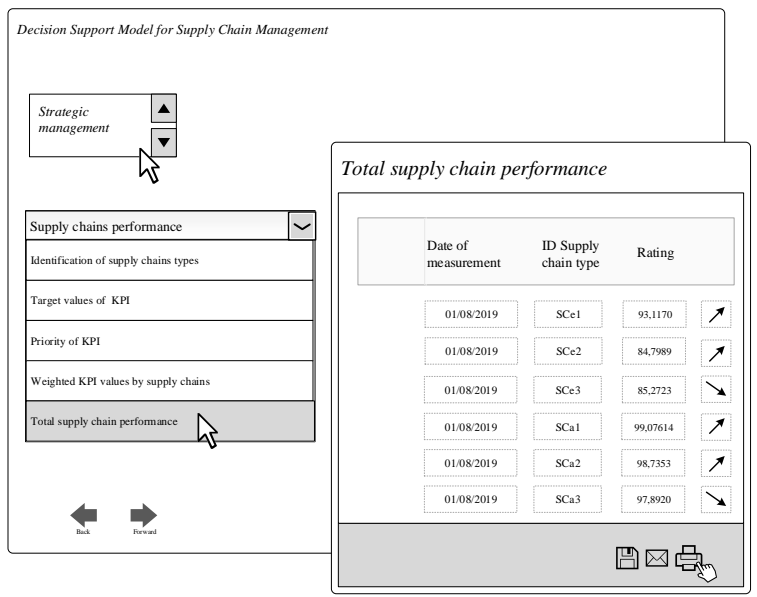

Figure 23. Total supply chain performance report Source: Authors 
For the needs of e-SCM, the prototype of a Web application that is being approached and performed within Web browser is also developed. The work with the Web application is started by the log-in of a user, by entering user name and password, depending on the right that the user has, all or some options in the menu are allowed. The home page of the Web application is presented in Figure 24.

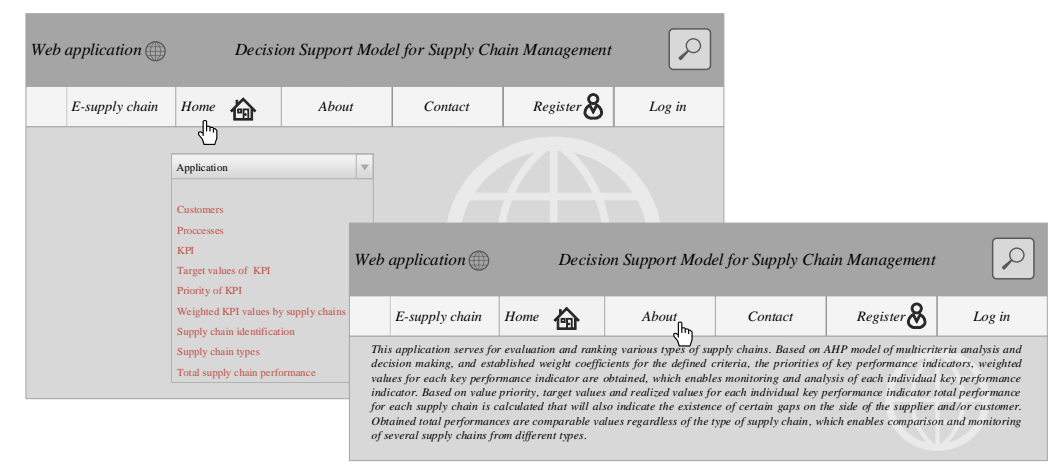

Figure 24. Software application web page Source: Authors

The user with authorization that allows him entry or changes has the possibility to, by activating displayed items, approach different forms both to perform new entry and/or update the existing data. By activating items, e.g. Target KPI, the user accesses the form for entry, changes and deletions of measured and target KPI values of business processes in supply chains.

\section{CONCLUSION}

The developed models and the web application enable all organizations in the supply chain to monitor the target and current values of key performance indicators and the total supply chain performance. Having such information at disposal offers the members of supply chains to simulate various values of each KPI in the set and analyze its impact on the total supply chain performance. In this way, the management of supply chain organizations is able to analyze, measure and rank several supply chains of different types, and evaluate which supply chain requires a correction in the specific KPI for the purpose of the improvement of its total performance, as well how the correction of certain KPI will affect the total performance of that supply chain. Moreover, the web application enables the monitoring of supply chain performances in time so it is possible to compare performances during various time periods. The developed prototype of the web application can be applied in various ERP organization systems of supply chain members. 


\section{REFERENCES}

Arsovski, Z. \& Rejman Petrović, D. (2017). Balanced Scorecard Framework for Developing Decision Support System Models in E-Supply Chains, "Knowledge Economy - Society, Management in the Face of Contemporary Challenges and Dilemmas", Eds. A. Jaki, B. Mikuła, Cracow University of Economics, Foundation of the Cracow University of Economics, Cracow 2017, pp.101-113

Chibba, A. (2007). Measuring supply chain performance measures: prioritizing performance measures. Lulea: Lulea tekniska universitet. (Licentiate thesis / Lulea University of Technology; No. 2007:49).

Croxton, K.L., Garcia-Dastugue, S.J. \& Lambert, D.M. (2001), The supply chain management process, The International Journal of Logistics Management, Vol. 21 No. 2, pp. 13-36

Deng, X., Hu, Y., Deng, Y., \& Mahadevan, S. (2014). Supplier selection using AHP methodology extended by D numbers. Expert Systems with Applications, 4l(1), 156-167.

Dweiri, F., Kumar, S., Khan, S. A., \& Jain, V. (2016). Designing an integrated AHP based decision support system for supplier selection in automotive industry. Expert Systems with Applications, 62, 273-283

Forslund, H. (2015), Performance management process integration in retail supply chains, International Journal of Retail \& Distribution Management, Vol. 43 No. 7, pp. 652-670.

Guan, W. \& Rehme, J. (2012), Vertical integration in supply chains: driving forces and consequences for a manufacturer's downstream integration, supply chain management, Supply Chain Management: An International Journal, Vol. 17 No. 2, pp. 187-201.

Ishizaka, A. \& Labib, A. (2011). Review of the main developments in the analytic hierarchy process. Expert Systems with Applications, 38(11), 14336-14345

Lambert, D.M., Garcia-Dastugue, S.J. \& Croxton, K.L. (2008), The role of logistics managers in the crossfunctional implementation of supply chain management, Journal of Business Logistics, Vol. 29 No. 1, pp. 113-133.

Li, S. \& Lin, B. (2006), Accessing information sharing and information quality in supply chain management, Decision Support Systems, Vol. 42 No. 3, pp. 1641-1656.

Lo, V.H.Y. \& Yeung, A.H.W. (2004), Practical framework for strategic alliance in Pearl River Delta manufacturing supply chain: a total quality approach, International, Journal of Production Economics, Vol. 87 No. 3, pp. 231-240

Mellat-Parast, M. \& Spillan, J.E. (2014), Logistics and supply chain process integration as a source of competitive advantage, The International Journal of Logistics Management, Vol. 25 No. 2, pp. 289-314

Panahifar, F., Byrne, P.J., Salam, M.A. \& Heavey, C. (2018), Supply chain collaboration and firm's performance: the critical role of information sharing and trust, Journal of Enterprise Information Management, Vol. 31 No. 3, pp. 358-379.

Rejman Petrović, D. (2016). Economic Horizons, September - December 2016, Vol. 18 , No. 3, pp. $209-226$

Rejman Petrović, D. (2015). Unapređenje poslovnih procesa u e-lancima snabdevanja, Doktorska disertacija, Ekonomski fakultet Univerziteta u Kragujevcu

Saaty, T. L., (1980). The Analytic Hierarchy Process, New York, McGraw-Hill.

Saaty, T. L. \& Kearns, P. K. (1985). Analytical planning, The Organization of Systems. The Analytic Hierarchy Process Series, Vol. IV, RWS Publications, Pittsburgh 
Sahay, B.S., Gupta, J.D. \& Mohan, R. (2006), Managing supply chains for competitiveness: the Indian scenario, Supply Chain Management: An International Journal, Vol. 11 No. 1, pp. 15-24.

Sanders, N.R., Autry, C.W. \& Gligor, D.M. (2011), The impact of buyer firm information connectivity enablers on supplier firm performance: a relational view, The International Journal of Logistics Management, Vol. 22 No. 2, pp. 179-201.

\section{МОДЕЛ ПОДРШКЕ ОДЛУЧИВАЊУ ЗА УПРАВЉАЊЕ ЛАНЦИМА СНАБДЕВАЊА}

Драгана Рејман Петровић, Предраг Мимовић, Зора Арсовски

Универзитет у Крагујевцу, Економски факултет, Крагујевац, Република Србија

\section{Резиме}

У овом раду фокус је стављен на мерење укупне перформансе ланца снабдевања и рад илуструје могућност евалуације и упоређивања различитих типова ланаца снабдевања, јер су се аутори досадашњих истраживања углавном бавили појединачним индикаторима перформанси ланца снабдевања или евалуацијом и рангирањем добављача у ланцима снабдевања. Дакле, у овом раду акценат је стављен на укупну меру ланца снабдевања, која је добијена пондерисањем и интеграцијом појединачних индикатора перформанси који су претходно идентификовани као кључни у процесу евалуације комплетног ланца снабдевања.

У оквиру овог рада приказани су развијени модел за евалуацију и рангирање различитих типова ланаца снабдевања, модел калкулације укупне перформансе ланаца снабдевања и развијени прототип система за подршку одлучивању у ланцима снабдевања.

Предложили модел за евалуацију и рангирање различитих типова ланаца снабдевања обухвата два модула. Први модул подразумева дефинисање типова посматраних ланаца снабдевања, кључних индикатора перформанси, њихових приоритета и циљних вредности у зависности од типа ланца снабдевања, евалуацију и рангирање различитих типова на основу АНР модела. Излази из овог модула представљају улазе који омогућавају функционисање другог модула који се тиче калкулације укупне перформансе ланца снабдевања.

Циљеви овог истраживања су: утврђивање кључних критеријума у процесу евалуације и рангирања ланаца снабдевања, израда АНР модела вишекритеријумског одлучивања вредновање постављених критеријума и њихова евалуација помоћу АНР метода и тестирање модела помоћу софтвера за подршку у одлучивању SuperDecisions и анализа добијених резултата.

Применом АНР метода приказана је: могућност евалуација и рангирање више ланаца снабдеваља у оквиру истог типа ланаца снабдевања, калкулација укупне перформансе ланаца снабдевања, могућност међусобног упоређивања перформанси ланаца снабдевања из различитих типова, анализе утицаја промене релативне важности изабраних критеријума на коначне приоритете и ранг ланца снабдевања, анализе утицаја промене приоритета поткритеријума (дефинисаних КPI) на приоритет и ранг ланца снабдевања и евалуације добављача и одређивање њиховог приоритета и ранга у зависности од тога којем типу ланца снабдевања припадају. 
Излази из АНР инкорпорирани су у базу података, тако да су у менаџмент информациони систем за унапређење пословних процеса у е-ланцима снабдевања укључени конкретни резултати до којих се дошло вишекритеријумском оптимизацијом предложеног модела, као и знања експерата који су консултовани приликом израде овог рада. Све ово чини овај систем системом за подршку одлучивању, имајући у виду да му је основни циљ да подржи пословне процесе доношења одлука. Основна намена је да помогне менаџменту да идентификује, структурира и реши полуструктуриране и неструктуриране проблеме, те да направи избор између различитих алтернатива.

Развијени модели и веб-апликација омогућавају свим чланицама ланца снабдевања увид у кретање кључних индикатора перформанси и укупне перформансе ланца снабдевања кроз познавање приоритета и пондера КРI за различите типове ланаца снабдевања и кроз праћење циљних и тренутних вредности кључних индикатора перформанси пословних процеса у различитим типовима ланаца снабдевања. 